\title{
C(sp2)-C(sp2) cross coupling reaction catalyzed by a palladacycle phosphine complex: A simple and sustainable protocol in aqueous media
}

\author{
SEYYED JAVAD SABOUNCHEI* and MARJAN HOSSEINZADEH \\ Faculty of Chemistry, University of Bu-Ali Sina, Hamedan, 65174 Iran \\ e-mail: jsabounchei@yahoo.co.uk
}

MS received 6 June 2015; revised 25 July 2015; accepted 4 August 2015

\begin{abstract}
The Heck reactions of various aryl halides with olefins using $\left\{\left[\mathrm{Ph}_{2} \mathrm{PCH}_{2} \mathrm{PPh}_{2} \mathrm{CH}=\mathrm{C}(\mathrm{O})\left(\mathrm{C}_{10} \mathrm{H}_{7}\right)\right]\right.$ $\left.\mathrm{PdCl}_{2}\right\}$ as efficient catalyst has been investigated. The mononuclear palladacycle complex showed excellent activity in aqueous phase including the $\mathrm{C}\left(\mathrm{sp}^{2}\right)-\mathrm{C}\left(\mathrm{sp}^{2}\right)$ cross coupling reactions. The advantages of the protocol are high yields, short reaction time, a cleaner reaction profile and notable simplicity.
\end{abstract}

Keywords. Palladium complex; Heck cross-coupling reaction; low catalyst loading; aerobic conditions.

\section{Introduction}

Heck reaction, one of the most widely adopted methods for the construction of carbon-carbon bonds in modern organic chemistry, is commonly carried out in the presence of a palladium complex. ${ }^{1-4}$ The resulting products play a significant role in the synthesis of bioactive compounds and organic products and are exploited in pharmaceutical industry applications. ${ }^{5,6}$ Development in this area is based on designing selective and stable palladium complex ctalysts with high turnover. Designing a suitable ligand is one of the first and important factor for this purpose. Among several types of ligand, phosphines exhibited the highest activity and selectivity in the Heck reactions..$^{7-13}$

Palladium-phosphine catalytic systems being employed in Heck coupling reactions have shown high efficiency in the formation of $\mathrm{C}-\mathrm{C}$ bonds. ${ }^{14-17} \mathrm{~A}$ number of Pd catalysts, usually simple palladium complexes associated with appropriate ligands, can catalyze this reaction under various reaction conditions. Among them, palladacycle complexes have been extensively applied in coupling reactions as effective catalysts, due to their ready preparation and modification, high activity and relative stability. ${ }^{18-20}$ For these reasons, this field is still challenging and in its infancy and the development of novel and greener protocols for the Heck cross-coupling reaction are desirable.

In this context, we were interested to explore the use of a five-membered chelate ring palladacycle, which

*For correspondence has been reported in our previous work, ${ }^{21}$ as a catalyst precursor for Heck cross-coupling in aqueous environments. This complex gives a high catalytic activity and a cleaner reaction profile in the coupling reactions of various aryl halides and olefins under aerobic conditions.

\section{Experimental}

\subsection{General}

All chemicals obtained from commercial suppliers were reagent grade and used without further purification. Fourier transform IR spectra were recorded on a Shimadzu 435-U-04 spectrophotometer, in the 200-4000 $\mathrm{cm}^{-1}$ region. NMR spectra were obtained on $500 \mathrm{MHz}$ and $90 \mathrm{MHz}$ Bruker spectrometers in $\mathrm{CDCl}_{3}$ as solvent. Melting points were determined using an SMP3 apparatus.

\subsection{General procedure for Mizoroki-Heck reaction}

A reaction tube was charged with the required aryl halide $(1 \mathrm{mmol})$, ethyl acrylate $(2.2 \mathrm{mmol})$ or styrene (2.2 mmol), Pd catalyst $(0.001 \mathrm{~mol} \%)$ and base $(1.5$ $\mathrm{mmol})$ in $\mathrm{NMP} / \mathrm{H}_{2} \mathrm{O}$ or $\mathrm{DMF} / \mathrm{H}_{2} \mathrm{O}(2 \mathrm{~mL}, 1: 1)$. The reaction mixture was stirred for the required period of time at $110^{\circ} \mathrm{C}$ until completion of the reaction, as monitored by TLC. After completion of the reaction, the mixture was diluted with n-hexane $(15 \mathrm{~mL})$ and water $(15 \mathrm{~mL})$. The combined organic phase was dried with $\mathrm{CaCl}_{2}$, solvent was removed and the product was recrystallized from ethanol. Yields were calculated 
against consumption of the aryl halides and pure products were identified by FTIR, ${ }^{1} \mathrm{H}$ and ${ }^{13} \mathrm{C}$ NMR spectroscopy and melting point analysis (See supplementary information).

\subsection{Characterization of cross-coupling products}

2.3a (E)-Ethyl 3-phenylacrylate: [Table 4, entries 1 (Yield: 0.151 g, 84\%), 3 (0.144 g, 80\%), 9 (0.135 g, $75 \%)$; 1a] Light yellow liquid, ${ }^{1} \mathrm{H}$ NMR (ppm): $\delta=$ $7.68(\mathrm{~d}, 1 \mathrm{H}, \mathrm{J}=16.03 \mathrm{~Hz}), 7.36-7.52(\mathrm{~m}, 5 \mathrm{H}), 6.43(\mathrm{~d}$, $1 \mathrm{H}, \mathrm{J}=16.01 \mathrm{~Hz}), 4.26(\mathrm{q}, 2 \mathrm{H}, \mathrm{J}=7.16 \mathrm{~Hz}), 1.33(\mathrm{t}$, $3 \mathrm{H}, \mathrm{J}=7.10 \mathrm{~Hz}) .{ }^{13} \mathrm{C}$ NMR $(\mathrm{ppm}): \delta=167.39(\mathrm{~s}, \mathrm{CO})$, $144.99,134.91,130.63,129.29,128.46,118.72,60.90$ $\left(\mathrm{CH}_{2}\right)$, and $14.74\left(\mathrm{CH}_{3}\right) .{ }^{22}$

2.3b (E)-Ethyl 3-(4-nitrophenyl)acrylate: [Table 4, entry 7 (Yield: $0.187 \mathrm{~g}, 83 \%$ ); 1e] Light yellow solid, M.P. $136-137^{\circ} \mathrm{C},{ }^{1} \mathrm{H}$ NMR (ppm): $\delta 8.23(\mathrm{~d}, 2 \mathrm{H}, \mathrm{J}$ $=8.72 \mathrm{~Hz}), 7.65-7.71(\mathrm{~m}, 3 \mathrm{H}), 6.47(\mathrm{~d}, 1 \mathrm{H}, \mathrm{J}=16.06$ $\mathrm{Hz}), 4.28$ (q, 2H, J = 7.09 Hz), $1.34(\mathrm{t}, 3 \mathrm{H}, \mathrm{J}=7.11$ $\mathrm{Hz}) .{ }^{13} \mathrm{C}$ NMR (ppm): $\delta=166.43$ (s, CO), 148.92, $142.02,141.02,129.03,124.59,123.04,61.43\left(\mathrm{CH}_{2}\right)$, and $14.68\left(\mathrm{CH}_{3}\right){ }^{23}$

2.3c (E)-Ethyl 3-(4-cyanophenyl)acrylate: [Table 4, entry 8 (Yield: $0.168 \mathrm{~g}, 82 \%$ ); 1f] Colorless solid, ${ }^{1} \mathrm{H}$ NMR (ppm): $\delta=7.67(\mathrm{~d}, 2 \mathrm{H}, \mathrm{J}=6.06 \mathrm{~Hz}), 7.59-7.66$ $(\mathrm{m}, 3 \mathrm{H}), 6.51(\mathrm{~d}, 1 \mathrm{H}, \mathrm{J}=16.03 \mathrm{~Hz}), 4.28(\mathrm{q}, 2 \mathrm{H}, \mathrm{J}=$ $7.12 \mathrm{~Hz}$ ), 1.34 (t, 3H, J = 7.05 Hz). ${ }^{13} \mathrm{C}$ NMR (ppm): $\delta 166.54(\mathrm{CO}), 142.53,139.19,133.06,128.79,122.33$, $118.77,113.79,61.35\left(\mathrm{CH}_{2}\right)$, and $14.68\left(\mathrm{CH}_{3}\right)$.

2.3d (E)-1,2-diphenylethene: [Table 4, entries 1 (Yield: $0.143 \mathrm{~g}, 81 \%), 3$ (0.127 g, 72\%), 9 (0.121 g, $69 \%$ ); 2a] Colorless plates, M.P. $122-124^{\circ} \mathrm{C},{ }^{1} \mathrm{H}$ NMR (ppm): $\delta 7.50(\mathrm{~d}, 4 \mathrm{H}, \mathrm{J}=7.7 \mathrm{~Hz}), 7.34(\mathrm{t}, 4 \mathrm{H}, \mathrm{J}=7.6$ $\mathrm{Hz}), 7.25$ (t, 2H, J = 7.4 Hz), 7.10 (s, 2H). 13C NMR (ppm): $\delta 137.81,129.18,129.15,128.09,126.99 .{ }^{24}$

2.3e 1-methyl-4-styrylbenzene: [Table 4, entries 2 (Yield: $0.148 \mathrm{~g}, 78 \%), 4$ (0.140 g, 74\%), 10 (0.120 g, 63\%); 2b] White plates, M.P. $116-117^{\circ} \mathrm{C},{ }^{1} \mathrm{H}$ NMR (ppm): $\delta 7.52(\mathrm{~d}, 2 \mathrm{H}, \mathrm{J}=7.26 \mathrm{~Hz}), 7.43(\mathrm{~d}, 2 \mathrm{H}, \mathrm{J}$ $=8.08 \mathrm{~Hz}), 7.36(\mathrm{t}, 2 \mathrm{H}, \mathrm{J}=7.84 \mathrm{~Hz}), 7.25(\mathrm{t}, 1 \mathrm{H}, \mathrm{J}$ $=7.34 \mathrm{~Hz}), 7.18(\mathrm{~d}, 2 \mathrm{H}, \mathrm{J}=7.90 \mathrm{~Hz}), 7.05-7.12(\mathrm{~m}$, $2 \mathrm{H}), 2.37(\mathrm{~s}, 3 \mathrm{H}),{ }^{13} \mathrm{C}$ NMR $(\mathrm{ppm}): \delta=159.32(\mathrm{~s}$, CO), 137.97, 137.93, 134.96, 129.84, 129.10, 129.04, $128.11,127.85,126.86,126.83$ and $21.72\left(\mathrm{CH}_{3}\right){ }^{24}$ 2.3f 4-styrylbenzonitrile: [Table 4, entry 8 (Yield: $0.167 \mathrm{~g}, 83 \%) ; 2 \mathrm{f}]$ White solid, M.P. $117-118^{\circ} \mathrm{C},{ }^{1} \mathrm{H}$ NMR (ppm): 7.52-7.64 (m, 6H), 7.39 (t, 2H, J = 7.50 $\mathrm{Hz}), 7.32$ (t, $1 \mathrm{H}, \mathrm{J}=7.40 \mathrm{~Hz}), 7.07-7.23(\mathrm{~m}, 2 \mathrm{H}) .{ }^{13} \mathrm{C}$ NMR (ppm): $\delta$ 142.26, 136.70, 132.94, 132.83, 129.31, $129.10,127.36,127.30,127.15,119.51$ and $110.98 .{ }^{25}$

2.3g cinnamaldehyde: [Table 4, entries 1 (Yield: $0.104 \mathrm{~g}, 79 \%), 3$ (0.092 g, 70\%), 9 (0.082 g, 62\%); 3a] Light yellow liquid, ${ }^{1} \mathrm{H}$ NMR (ppm): 6.68 (doublet of doublet, $1 \mathrm{H}, \mathrm{J}=7.75 \mathrm{~Hz}), 7.40-7.54(\mathrm{~m}, 6 \mathrm{H}), 9.67$ (d, $1 \mathrm{H}, \mathrm{J}=7.75 \mathrm{~Hz}) .{ }^{13} \mathrm{C}$ NMR $(\mathrm{ppm}): \delta 128.38,128.48$, $129.02,131.17,133.96,152.64$ and 193.57.

The following compounds gave data consistent with those published: Table 4: (E)-Ethyl 3-(4methylphenyl)acrylate [entries 2 (Yield: $0.151 \mathrm{~g}$, $78 \%), 4(0.141 \mathrm{~g}, 73 \%), 10(0.122,63 \%) ; 1 \mathrm{~b}],{ }^{26}$ (E)-Ethyl 3-(4-acetylphenyl)acrylate [entries 5 (Yield: $0.175 \mathrm{~g}, 79 \%), 11(0.155 \mathrm{~g}, 70 \%) ; 1 \mathrm{c}],{ }^{27}(\mathrm{E})-$ 1-(4-styrylphenyl)ethanone [entries 5 (Yield: 0.172 , 79\%), 11 (0.146 g, 67\%); 2c], ${ }^{24,28}$ 1-methoxy-4styrylbenzene [entries 6 (Yield: $0.130 \mathrm{~g}, 63 \%$ ), 12 $(0.121 \mathrm{~g}, \quad 59 \%) ; 2 \mathrm{~d}],{ }^{29}$ (E)-1-nitro-4-styrylbenzene [entry 7 (Yield: $0.179,81 \%) ; 2 \mathrm{e}$ ], ${ }^{29-31}$ (E)-3-(4nitrophenyl)acrylaldehyde [entry 7 (Yield: 0.136, $77 \%) ; 3 \mathrm{e}] .{ }^{24}$

\section{Results and Discussion}

It is well established that palladium complexes containing phosphine ligands, which combine both good donor strength and $\pi$-accepting capacity, always have a high catalytic activity in Heck cross-coupling reactions. ${ }^{18-20,32-37}$ Therefore we have attempted to use the palladium(II) complex as catalyst in $\mathrm{C}\left(\mathrm{sp}^{2}\right)-\mathrm{C}\left(\mathrm{sp}^{2}\right)$ cross coupling reaction (scheme 1). The ability to use small amounts of catalyst and still achieve high yields is a great concern in cross coupling reactions due to the high cost of metals and ligands.

The catalytic activity of the palladacycle complex was assessed in the Heck cross-coupling reaction, initially by studying the coupling of 1-bromo-4nitrobenzene with styrene as a model reaction. Various parameters including solvent, base and catalyst loading were screened to optimize the reaction conditions. Initially, the coupling reaction was set up in the presence of DMF solvent, $\mathrm{K}_{2} \mathrm{CO}_{3}$ base and $0.01 \mathrm{~mol} \%$ catalyst loading at $130^{\circ} \mathrm{C}$ for $3 \mathrm{~h}$ (the obtained yield was $81 \%$ ). As shown in scheme 1 , the results of this reaction indicate that the $\mathrm{Pd}(\mathrm{II})$ complex catalyzed the olefin coupling reaction with 1-bromo-4-nitrobenzene to form exclusively trans stilbene as established by 


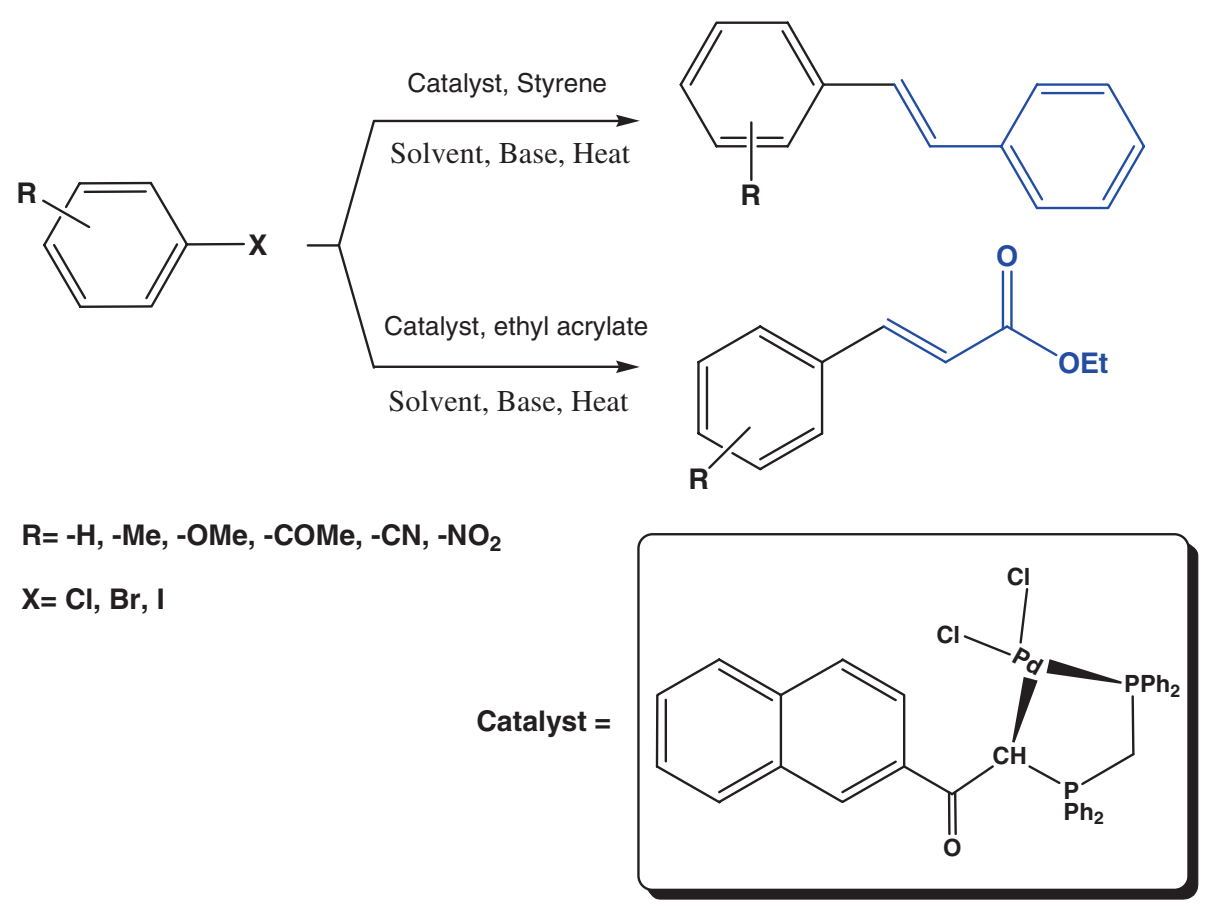

Scheme 1. $\mathrm{C}\left(\mathrm{sp}^{2}\right)-\mathrm{C}\left(\mathrm{sp}^{2}\right)$ cross-coupling reaction.

${ }^{1} \mathrm{H}$ NMR and ${ }^{13} \mathrm{C}$ NMR analysis. No other coupling products (cis or gem isomers) were observed. This is in agreement with general Mizoroki-Heck coupling reaction so that the linear isomers ( $E$-isomer) is favorable and were selectively obtained as confirmed by spectroscopic analysis. ${ }^{38}$

The effect of catalyst loading was investigated, using different quantities of the catalyst ranging from 0.0005 to $0.10 \mathrm{~mol} \%$. The best results were obtained using $0.001 \mathrm{~mol} \%$ of catalyst (table 1 ). No significant improvement in the reaction results was observed upon further increasing the quantity of catalyst. As this catalyst is not sensitive to oxygen, the reactions were carried out in the air atmosphere.

Additional studies were carried out in order to optimize the effect of different solvents and bases (tables 2 and 3). Water, $\mathrm{H}_{2} \mathrm{O} / \mathrm{DMF}$, methanol, DMF, NMP, $\mathrm{H}_{2} \mathrm{O}$ / NMP and dioxane were investigated, and the best

Table 1. Optimization of catalyst concentration.

\begin{tabular}{|c|c|c|c|c|}
\hline \multirow[b]{3}{*}{ Entry } & \multirow{2}{*}{$\mathrm{ArX}+$} & $\mathrm{Y}$ & Catalyst & \multirow[b]{3}{*}{ Isolated yield (\%) } \\
\hline & & \multicolumn{2}{|c|}{ Solvent, Base, Heat } & \\
\hline & Catalyst (mol\%) & Time (h) & Reaction condition ${ }^{\mathrm{a}, \mathrm{b}}$ & \\
\hline 1 & None & 10 & Styrene $^{a}$, ethyl acrylate ${ }^{b}$ & $\mathrm{NR}^{\mathrm{c}}$ \\
\hline \multirow[t]{2}{*}{2} & 0.10 & 3 & Styrene & 90 \\
\hline & & & Ethyl acrylate ${ }^{\mathrm{b}}$ & 89 \\
\hline \multirow[t]{2}{*}{3} & 0.01 & 3 & Styrene ${ }^{\mathrm{a}}$ & 81 \\
\hline & & & Ethyl acrylate ${ }^{\mathrm{b}}$ & 85 \\
\hline \multirow[t]{2}{*}{4} & 0.001 & 3 & Styrene ${ }^{\mathrm{a}}$ & 80 \\
\hline & & & Ethyl acrylate ${ }^{b}$ & 85 \\
\hline \multirow[t]{2}{*}{5} & 0.0005 & 5 & Styrene ${ }^{a}$ & 68 \\
\hline & & & Ethyl acrylate ${ }^{\mathrm{b}}$ & 73 \\
\hline
\end{tabular}

${ }^{\mathrm{a}}$ Reaction conditions: 1-bromo-4-nitrobenzene $(1 \mathrm{mmol})$, Styrene $(2.2 \mathrm{mmol}), \mathrm{K}_{2} \mathrm{CO}_{3}(1.5 \mathrm{mmol})$, $\operatorname{DMF}(2 \mathrm{ml})$, in the air, $130^{\circ} \mathrm{C}$.

${ }^{\mathrm{b}}$ Reaction conditions: 1-bromo-4-nitrobenzene $(1 \mathrm{mmol})$, ethyl acrylate $(2.2 \mathrm{mmol}), \mathrm{Cs}_{2} \mathrm{CO}_{3}(1.5$ $\mathrm{mmol})$, NMP $(2 \mathrm{ml})$, in the air, $130^{\circ} \mathrm{C}$.

${ }^{\mathrm{c}}$ No Reaction. 
Table 2. Optimization of base and solvent for Heck cross-coupling reaction of 1-bromo-4-nitrobenzene with styrene. ${ }^{[a]}$

\begin{tabular}{|c|c|c|c|c|c|}
\hline Entry & Base & Solvent & Temp $\left({ }^{\circ} \mathrm{C}\right)$ & Time (h) & Isolated yield (\%) \\
\hline 1 & $\mathrm{~K}_{2} \mathrm{CO}_{3}$ & methanol & 60 & 10 & 63 \\
\hline 2 & $\mathrm{~K}_{2} \mathrm{CO}_{3}$ & DMF & 130 & 4 & 81 \\
\hline 3 & $\mathrm{~K}_{2} \mathrm{CO}_{3}$ & $\mathrm{DMF} / \mathrm{H}_{2} \mathrm{O}$ & 110 & 4 & 81 \\
\hline 4 & $\mathrm{~K}_{2} \mathrm{CO}_{3}$ & $\mathrm{H}_{2} \mathrm{O}$ & 90 & 5 & 66 \\
\hline 5 & $\mathrm{~K}_{2} \mathrm{CO}_{3}$ & NMP & 130 & 6 & 72 \\
\hline 6 & $\mathrm{~K}_{2} \mathrm{CO}_{3}$ & dioxane & 110 & 9 & 60 \\
\hline 7 & $\mathrm{Cs}_{2} \mathrm{CO}_{3}$ & $\mathrm{DMF} / \mathrm{H}_{2} \mathrm{O}$ & 110 & 6 & 77 \\
\hline 8 & $\mathrm{Na}_{2} \mathrm{CO}_{3}$ & $\mathrm{DMF} / \mathrm{H}_{2} \mathrm{O}$ & 110 & 10 & 68 \\
\hline 9 & $\mathrm{NaOAc}$ & $\mathrm{DMF} / \mathrm{H}_{2} \mathrm{O}$ & 110 & 10 & 55 \\
\hline 10 & $\mathrm{NaF}$ & $\mathrm{DMF} / \mathrm{H}_{2} \mathrm{O}$ & 110 & 12 & 59 \\
\hline
\end{tabular}

[a] Reaction conditions: 1-bromo-4-nitrobenzene ( $1 \mathrm{mmol})$, Styrene $(2.2 \mathrm{mmol})$, base $(1.5 \mathrm{mmol})$ and $2 \mathrm{~mL}$ solvent.

yields were observed with water/DMF $(2 \mathrm{~mL}, 1: 1)$ and water/NMP (2 mL, 1:1) for styrene and ethyl acrylate, respectively (tables 2 and 3). By testing different temperatures in the range of 60 to $130^{\circ} \mathrm{C}$, a change in yield was observed. The highest yield was obtained at $110^{\circ} \mathrm{C}$. Base has a main function in Mizoroki-Heck reaction mechanism to neutralize the acidic condition of hydrogen halide in the reductive elimination step and regenerate the catalyst to continue catalytic cycle. ${ }^{39,40}$ Inorganic bases such as $\mathrm{K}_{2} \mathrm{CO}_{3}$ and $\mathrm{Cs}_{2} \mathrm{CO}_{3}$, because of their excellent capability to neutralize protons generated in the oxidative addition mechanistic step, were found to be more effective than the other bases such as $\mathrm{Na}_{2} \mathrm{CO}_{3}, \mathrm{NaOAc}$ and $\mathrm{NaF}$ that afforded moderate yield of coupling products.

The reaction was then investigated with different aryl halides and olefins at the determined optimized conditions and the results are summarized in table 4 . We used aryl iodide to test the catalytic activity of the $\mathrm{Pd}(\mathrm{II})$ catalyst.

The time of reaction for aryl iodide was shorter than that for aryl bromides $(3 \mathrm{~h})$ and very good to

Table 3. Optimization of base and solvent for Heck cross-coupling reaction of 1-bromo-4-nitrobenzene with ethyl acrylate. $^{[\mathrm{a}]}$

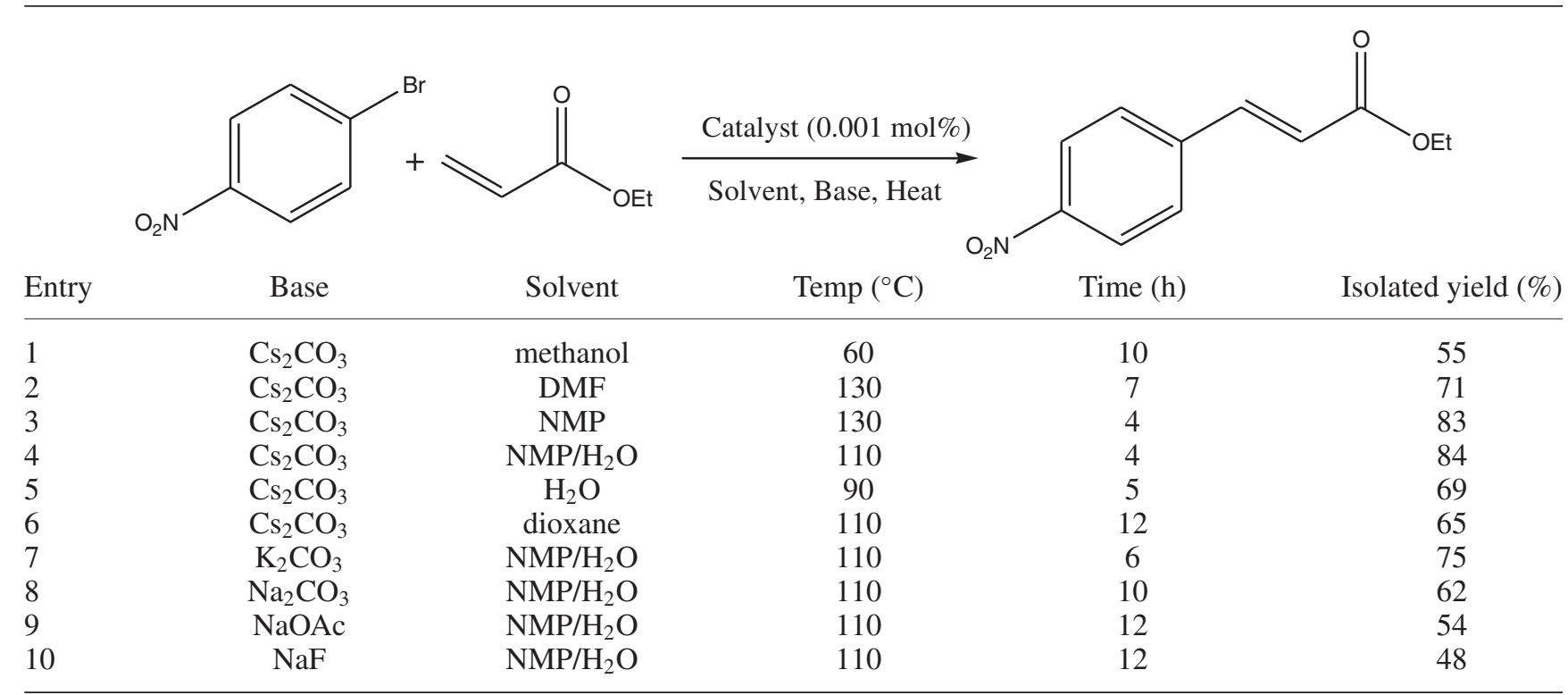

[a] Reaction conditions: 1-bromo-4-nitrobenzene (1 mmol), Ethyl acrylate $(2.2 \mathrm{mmol})$, base $(1.5 \mathrm{mmol})$ and $2 \mathrm{~mL}$ solvent. 
Table 4. Heck cross-coupling reaction of aryl halides with olefins catalyzed by $\mathrm{Pd}$ complexes. $^{\text {a,b,c }}$

\begin{tabular}{lccc}
\hline Entry & Pryl halide & time (h) & Yield (\%) \\
\hline 1 & & & \\
& $\mathbf{1 a}$ & 3 & 84 \\
& $\mathbf{2 a}$ & 3 & 79
\end{tabular}

2<smiles>Cc1ccc(I)cc1</smiles>

$1 \mathrm{~b}$

$2 b$<smiles>Brc1ccccc1</smiles>

3

$1 \mathrm{a}$

$2 \mathrm{a}$

$3 a$<smiles>Cc1ccc(Br)cc1</smiles>

5<smiles>CC(=O)c1ccc(Br)cc1</smiles>

6<smiles>COc1ccc(Br)cc1</smiles>

7<smiles>O=[N+]([O-])c1ccc(Br)cc1</smiles>

8<smiles>N#Cc1ccc(Br)cc1</smiles>

9<smiles>Clc1ccccc1</smiles>

\section{$1 b$}

$2 b$

$1 c$

2c

$1 d$

2d

$1 \mathrm{e}$

$2 \mathrm{e}$

3 e

$1 f$

2 f

$1 \mathrm{a}$

$2 \mathrm{a}$

$3 a$<smiles>Cc1ccc(Cl)cc1</smiles>

10<smiles>CC(=O)c1ccc(Cl)cc1</smiles>

$1 \mathrm{~b}$

$2 b$

$1 c$

2c
80

72

70

73

74

79

79

67

63

83

81

77

82

83

75

69

62

63

63

70

67 
Table 4. (continued)

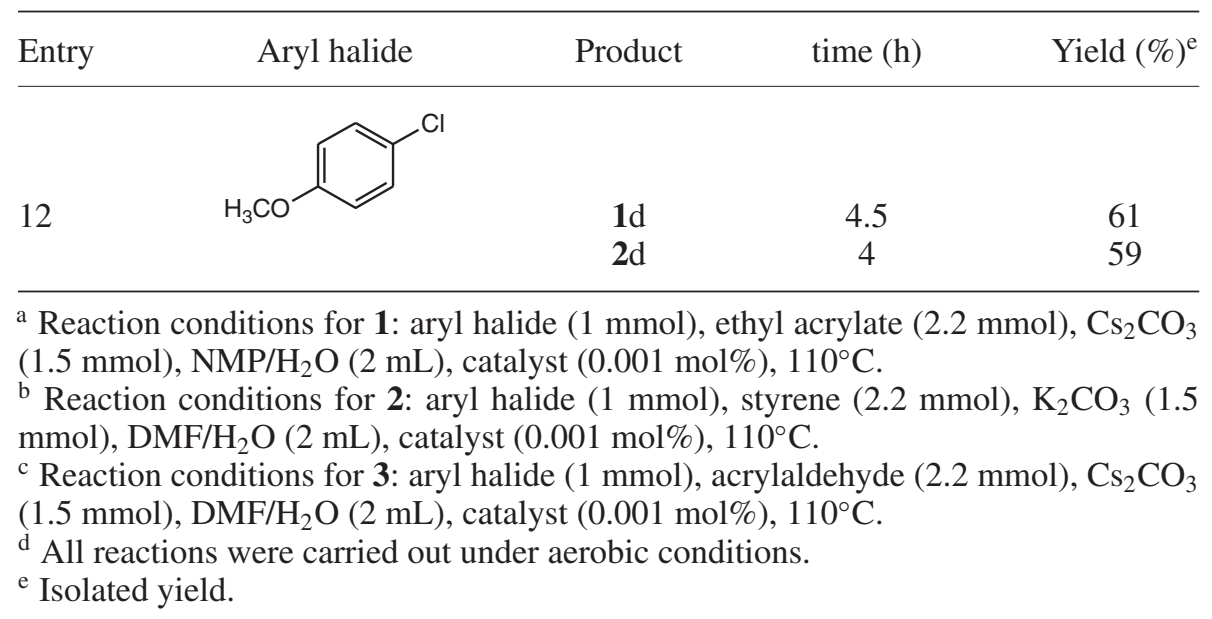

excellent yields were obtained. As shown in table 4, Heck reaction of activated aryl bromides such as 4nitrobromobenzene and 4-bromobenzonitrile with ethyl acrylate and styrene under similar conditions underwent to afford the corresponding products in 81$83 \%$ yields (table 4, entries 7 and 8 ; 1e (83\%), 2e $(81 \%)$, $\mathbf{1 f}(82 \%)$ and $\mathbf{2 f}(83 \%))$ whereas, inactivated aryl bromides such as 4-methylbromobenzene and 4methoxybromobenzene gave $63-74 \%$ yields (table 4 , entries 4 and 6; 1b (73\%), 2b (74\%), 1d (67\%) and $\mathbf{2 d}$ $(63 \%))$. It is well known that the electron-withdrawing groups on the aryl ring increases the reaction rate and electron donating substituent makes the oxidative addition step more difficult. ${ }^{41}$

Although a number of reported catalysts in literature need to be used in high loadings, and showed little or no activity with aryl chloride substrates, ${ }^{42-44}$ there is much attention in industry to couple aryl chlorides with olefins due to the economical aspect of aryl chlorides and the challenge to activate the $\mathrm{C}-\mathrm{Cl}$ bond. ${ }^{45-47} \mathrm{As}$ expected, a low reactivity was observed when we used both of electron rich and deficient aryl chloride substrates in coupling reactions (table 4, entries 11 and 12; 1c $(70 \%), 2 c(67 \%), \mathbf{1 d}(61 \%)$ and 2d (59\%)). While aryl bromides or iodides reacted readily, aryl chlorides showed slower reaction rates due to the stronger $\mathrm{C}-\mathrm{Cl}$ bond. Aryl chlorides with electron-withdrawing groups (table 4, entry 11) reacted more easily than those with electron donating groups (table 4, entry 12).

As shown in table 5, the Heck reaction of both electron-rich and electron-deficient aryl chlorides also proceeded smoothly to furnish the desired products with good to excellent yields. For better comparison of the catalyst with the same one, as well as the optimal conditions, results of Heck reaction using other catalysts is presented in table 5 . On the whole, it can be seen that results obtained by using this Pd complex in most Heck reactions are similar to or slightly better than those of related bidentate chelating Pd complexes. ${ }^{48-53}$ The advantages associated with this complex is the freedom to easily modulate electronic and steric properties simply by changing (i) the size of metallocyclic ring, (ii) the nature of metallated carbon (aliphatic and/or aromatic groups), (iii) the type of donor group (C-, P-, $\mathrm{S}-, \mathrm{O}-, \mathrm{N}$ - coordinated) and (iv) the nature of the ligands (halides and bidentate ligands).

For example, Huynh et al. have modified a six homodicarbene $\mathrm{Pd}(\mathrm{II})$ complex to increase the reaction time of the corresponding olefin and thereby decrease the catalyst loading $(0.05 \mathrm{~mol} \%) .{ }^{50}$ But contrary to the expectations, poor results in terms of yield have been achieved for Heck reaction using this modified complex. Yen et al. used $\left[\mathrm{PdBr}_{2}(\mathrm{NHC})\left(\mathrm{CH}_{3} \mathrm{CN}\right)\right]^{51}$ as a catalyst for multiple vinylation of aryl halides with olefins. It is important to note that this complex does not provide satisfactory results as by using other commercially $\mathrm{Pd}$ catalysts (such as $\mathrm{Pd}(\mathrm{OAc})_{2}, \mathrm{PdCl}_{2}$, etc.). ${ }^{54}$ By comparison, it can be seen that this $\mathrm{Pd}$ complex has displayed some outstanding superiority as catalyst such as green condition, low catalyst loading and short reaction times. Considering table 5, it is obvious that this Pd complex (entry 1) has shown good catalytic activity for the Heck coupling reaction in the presence of $0.001 \mathrm{~mol} \%$ catalyst in green optimized condition compared to the other catalysts (0.002-1 mol\%) (entries 2-6), ${ }^{48-52}$ and $\left[\left(\left\{\mathrm{Ph}_{2} \mathrm{PCH}_{2} \mathrm{PPh}_{2} \mathrm{CH}\right\}\right.\right.$ $\left.\left.\mathrm{C}(\mathrm{O}) \mathrm{C}_{6} \mathrm{H}_{4} \mathrm{C}_{6} \mathrm{H}_{5}\right) \mathrm{PdCl}_{2}\right]^{53}$ reported previously. The activity of our catalyst in Heck coupling reactions is significantly improved. As shown in table 5, our catalyst is superior to some of the previously reported catalysts in terms of reaction condition, reaction time and yield. 
Table 5. Comparison with other catalytic systems.

\begin{tabular}{|c|c|c|c|c|c|c|}
\hline Entry [Ref.] & Pd catalyst & $\begin{array}{c}{[\mathrm{Pd}]} \\
(\mathrm{mol} \%)\end{array}$ & Reaction conditions & Aryl halide/ Olefin & Time (h) & eld $(\%)^{a}$ \\
\hline 1 [This Work] & & 0.001 & $\begin{array}{l}\mathrm{K}_{2} \mathrm{CO}_{3}, \mathrm{DMF} / \\
\text { Water, } 110^{\circ} \mathrm{C}\end{array}$ & $\begin{array}{l}\text { Iodobenzene/ Styrene } \\
\text { Bromobenzene/ Styrene } \\
\text { Chlorobenzene/ Styrene } \\
\text { 4-Bromoanisole/ Ethyl acrylate }\end{array}$ & $\begin{array}{l}3 \\
4 \\
4 \\
4\end{array}$ & $\begin{array}{l}81 \\
72 \\
69 \\
67\end{array}$ \\
\hline $2^{48}$ & & 0.001 & $\mathrm{~K}_{2} \mathrm{CO}_{3}, \mathrm{DMF}, 130^{\circ} \mathrm{C}$ & $\begin{array}{c}\text { Chlorobenzene/ Styrene } \\
\text { Chlorobenzene/ Ethyl acrylate }\end{array}$ & $\begin{array}{l}24 \\
24\end{array}$ & $\begin{array}{l}62 \\
71\end{array}$ \\
\hline $3^{49 b}$ & & 0.01 & $\mathrm{NaOAC}, \mathrm{DMF}, 95^{\circ} \mathrm{C}$ & Iodobenzene/ Styrene & 24 & 56 \\
\hline $4^{50}$ & & 0.05 & $\mathrm{NaOAC}, \mathrm{DMF}, 150^{\circ} \mathrm{C}$ & $\begin{array}{l}\text { Chlorobenzene/ } \\
\text { tert-butyl acrylate }\end{array}$ & 48 & 41 \\
\hline $5^{51}$ & & 1 & $\mathrm{NaOAC}, \mathrm{DMF}, 110^{\circ} \mathrm{C}$ & $\begin{array}{l}\text { 4-bromoanisole/ } \\
\text { tert-butyl acrylate }\end{array}$ & 17 & 53 \\
\hline $6^{52 c}$ & & 1 & $\mathrm{NaOAC}, \mathrm{DMF}, 140^{\circ} \mathrm{C}$ & $\begin{array}{l}\text { 4-Bromoanisole/ } \\
\text { tert-butyl acrylate }\end{array}$ & 24 & 72 \\
\hline $\begin{array}{l}7^{53} \\
8^{54 \mathrm{~d}}\end{array}$ & $\mathrm{Ac})_{2}$ & $\begin{array}{l}0.002 \\
0.001\end{array}$ & $\begin{array}{c}\mathrm{NaOAC}, \mathrm{DMF}, 95^{\circ} \mathrm{C} \\
(\mathrm{Et})_{3} \mathrm{~N}, \mathrm{IL}, 100^{\circ} \mathrm{C}\end{array}$ & $\begin{array}{l}\text { Iodobenzene/ Styrene } \\
\text { Iodobenzene/ Styrene }\end{array}$ & $\begin{array}{c}20 \\
4\end{array}$ & $\begin{array}{l}69 \\
86\end{array}$ \\
\hline
\end{tabular}

\section{Conclusion}

In this research, a palladacycle complex containing bidentate phosphine ligand was used as an efficient and well-defined catalyst for the $\mathrm{C}\left(\mathrm{sp}^{2}\right)-\mathrm{C}\left(\mathrm{sp}^{2}\right)$ crosscoupling reactions under ambient atmosphere. The described Pd(II) catalyst was observed to be stable and showed high catalyst activity in Heck cross-coupling reactions in water/DMF (2 mL, 1:1) and water/NMP (2 $\mathrm{mL}, 1: 1)$ solvent systems for styrene and ethyl acrylate, respectively. In comparison with previously reported catalysts, ${ }^{48}$ the salient features of the proposed catalyst include high efficiency and simplicity, which leads to short reaction time, high yields and a cleaner reaction profile.

\section{Supplementary Information}

The supplementary data contain IR, ${ }^{1} \mathrm{H}$ and ${ }^{13} \mathrm{C}$ NMR spectra of Heck coupling products (figures S1-S15). 
Supplementary Information is available at www.ias.ac. in/chemsci.

\section{References}

1. Heck R F and Nolley J P 1972 J. Org. Chem. 372320

2. Dupont J, Pfeffer M and Spencer J 2001 Eur. J. Inorg. Chem. 20011917

3. Albrecht M and Van Koten G 2001 Angew. Chem., Int. Ed. 403750

4. Phan N T S, Sluys M V D and Jones C W 2006 Adv. Synth. Catal. 348609

5. Miyaura N and Suzuki A 1995 Chem. Rev. 952457

6. Littke A F and Fu G C 2002 Angew. Chem., Int. Ed. 41 4176

7. Morales-Morales D, Redó R, Yung C and Jensen C M 2000 Chem. Commun. 1619

8. Littke A F and Fu G C 1999 J. Org. Chem. 6410

9. Shaughnessy K H, Kim P and Hartwig J F 1999 J. Am. Chem. Soc. 1212123

10. Ehrentraut A, Zapf A and Beller M 2000 Synlett 1589

11. Portnoy M, Ben-David Y, Rousso I and Milstein D 1994 Organometallics 133465

12. Ohff M, Ohff A, Van der Boom M E and Milstein D 1997 J. Am. Chem. Soc. 11911687

13. Bedford R B 2003 Chem. Commun. 1787

14. Stevens P D, Fan J, Gardimalla H M, Yen M and Gao Y 2005 Org. Lett. 72085

15. Zhu M and Diao G 2011 J. Phys. Chem. 11524743

16. Karimi B and Enders D 2006 Org. Lett. 81237

17. Elhamifar D, Karimi B, Rastegar J and Banakar M H 2013 ChemCatChem 52418

18. Aizawa S -I, Hase T and Wada T 2007 J. Organomet. Chem. 692813

19. Dupont J and Pfeffer M 2008 In Palladacycles: Synthesis, Characterization and Applications (New York: John Wiley)

20. Overman L E and Poon D J 1997 Angew. Chem. 36 518

21. Sabounchei S J, Panahimehr M, Ahmadi M, Nasri Z and Khavasi H R 2013 J. Organomet. Chem. 723207

22. (a) Imashiro R and Seki M 2004 J. Org. Chem. 69 4216; (b) Carmichael A J, Earle M J, Holbrey J D, McCormac P B and Seddon K R 1999 Org. Lett. 1 997; (c) Chen Y, Huang L Y, Ranade M A and Zhang X P 2003 J. Org. Chem. 683714

23. Huang X, Xie L and Wu H 1988 J. Org. Chem. 53 4862

24. Zhou L and Wang L 2006 Synthesis 162653

25. Iyer S, Kulkarni G M and Ramesh C 2004 Tetrahedron 60 2163

26. Casalnuovo A L and Calabrese J C $1990 \mathrm{~J}$. Am. Chem. Soc. 1124324

27. Caló V, Nacci A, Monopoli A, Laera S and Cioffi N 2003 J. Org. Chem. 682929

28. Solodenko W, Mennecke K, Vogt C, Gruhl S and Kirschning A 2006 Synthesis 111873
29. Aksin Ö, Tüerkmen H, Artok L, Cetinkaya B, Ni C Y, Büeyüekgüengöer O and Öezkal E 2006 J. Organomet. Chem. 6913027

30. Mu B, Li T, Xu W, Zeng G, Liu P and Wu Y 2007 Tetrahedron 6311475

31. (a) Inamoto K, Kuroda J -I, Hiroya K, Noda Y, Watanabe M and Sakamoto T 2006 Organometallics 25 3095; (b) Widegren J A and Finke R G $2003 \mathrm{~J}$. Mol. Catal. A 198 317; (c) Peris E, Loch J A, Mata J and Crabtree R H 2001 Chem. Commun. 201

32. Frey G D, Schütz J, Herdtweck E and Herrmann W A 2005 Organometallics 244416

33. Milde B, Schaarschmidt D, Ecorchard P and Lang H 2012 J. Organomet. Chem. 70652

34. Skarżyńska A, Trzeciak A M and Siczek M 2011 Inorg. Chim. Acta 365204

35. Sabounchei S J, Hosseinzadeh M, Panahimehr M, Nematollahi D, Khavasi H R and Khazalpour S 2015 Transit. Metal Chem. 1

36. Sabounchei S J, Ahmadi M, Nasri Z, Shams E, Salehzadeh S, Gholiee Y, Karamian R, Asadbegy M and Samiee S 2013 C. R. Chimie 16159

37. (a) Pascu S I, Coleman K S, Cowley A R, Green M L H and Rees N H 2005 New J. Chem. 29 385; (b) Gibson S, Foster D F, Eastham G R, Tooze R P and Cole-Hamilton D J 2001 Chem. Commun. 779; (c) Frey G D, Reisinger C P, Herdtweck E and Herrmann W A 2005 J. Organomet. Chem. 6903193

38. Ben-David Y, Portnoy M, Gozin M and Milstein D 1992 Organomettalics 111995

39. Li H, Wu Y -J, Xu C and Tian R -Q 2007 Polyhedron 264389

40. Jutand A 2004 Pure Appl. Chem. 76565

41. Whitcombe N J, Hii K K M and Gibson S E 2001 Tetrahedron $\mathbf{5 7} 7449$

42. Ren G, Cui X, Yang E, Yang F and Wu Y 2010 Tetrahedron 664022

43. Huynh H V, Ho J H H, Neo T C and Koh L L 2005 J. Organomet. Chem. $\mathbf{6 9 0} 3854$

44. Hajipour A R and Rafiee F 2011 J. Organomet. Chem. 6962669

45. Davison J B, Simon N M and Sojka S A 1984 J. Mol. Catal. 22349

46. Yi C and Hua R 2006 Tetrahedron Lett. 472573

47. Xu H -J, Zhao Y -Q and Zhou X -F 2011 J. Org. Chem. 768036

48. Sabounchei S J, Ahmadi M, Azizi T and Panahimehr M 2014 Synlett 25336

49. Shaw B L 2004 Chem. Commun. 121361

50. Huynh H V and Jothibasu R $2011 \mathrm{~J}$. Org. Chem. 696 3369

51. Yen S K, Koh L L, Hahn F E, Huynh H V and Hor T A 2006 Organometallics 255105

52. Han Y, Huynh H V and Koh L L 2007 J. Org. Chem. 6923606

53. Shaw B 1998 Chem. Commun. 171863

54. Wang Y, Luo J and Liu Z 2013 J. Organomet. Chem. 7391 